\title{
UTJECAJ MIKORIZE NA NICANJE KORALJNOG ZVONČIĆA (HEUCHERA SANGUINEA 'METALLICA')
}

\author{
THE INFLUENCE OF MYCORRHIZAE ON GERMINATION OF \\ CORAL BELLS (HEUCHERA SANGUINEA 'METALLICA')
}

\author{
Ines Han Dovedan, Ana Brajković, M. Poje
}

\section{SAŽETAK}

Vrste roda Heuchera L. pripadaju skupini trajnica koje se najčešće primjenjuju za uređenje cvjetnih gredica i kamenjara. Osim cvijeta, posjeduju privlačno lišće, što ih čini zanimljivima kroz cijelu godinu. Pri generativnom razmnožavanju koje je zastupljeno u značajnoj mjeri u proizvodnji trajnica, često dolazi do problema sporog nicanja, što poskupljuje troškove proizvodnje, pa je stoga poželjan što kraći period od sjetve do nicanja.

Cilj rada je bio utvrditi utjecaj endomikorizne gljive Glomus mossae na dinamiku nicanja sjemena i razvoj listova kod kultivara Heuchera sanguinea Engelm. 'Metallica'. Sjeme je posijano u prethodno inokulirani supstrat sporama endomikorizne gljive Glomus mossae u dvije različite koncentracije, od 2,5\% vol. i $5 \%$ vol.

Rezultati istraživanja pokazuju da je endomikorizna gljiva Glomus mossae imala pozitivan učinak na dinamiku nicanja u usporedbi s kontrolom. Pozitivan učinak Glomus mossae izostao je kod razvoja listova, u manjoj koncentraciji inokuluma u supstratu (2,5\%) vol., u usporedbi s kontrolom.

Ključne riječi: Heuchera sanguinea Engelm. 'Metallica', Glomus mossae, mikoriza, dinamika nicanja

\begin{abstract}
Species of the genus Heuchera L. belong to the group of perennials that are commonly used for decorating flowerbeds and rockeries. Besides flowers they possess attractive leaves, which make them attractive throughout the year. In generative reproduction of perennials slow germination is often a problem which raises production costs. Therefore, it is desirable to have as short a period from sowing to germination.
\end{abstract}


Ines Han Dovedan i sur.: Utjecaj mikorize na nicanje koraljnog zvončića (Heuchera sanguinea 'Metallica')

The aim of this study was to determine the effect of mycorrhizal fungi Glomus mossae in two different concentrations of inoculum on the dynamics of seed germination the cultivar Heuchera sanguinea Engelm. 'Metallica'. Seeds were sown in substrate previously inoculated with spores of mycorrhizal fungi Glomus mossae in two different concentrations of $2.5 \% \mathrm{vol}$ and $5 \% \mathrm{vol}$.

The research results show that the mycorrhizal fungus Glomus mossae had a positive effect on the dynamics of the germination compared with the control. The positive effect of Glomus mossae was missing in the development of leaves, with a lower concentration of inoculum in the substrate $(2,5 \% \mathrm{vol})$, compared with the control.

Key words: Heuchera sanguinea Engelm. 'Metallica', Glomus mossae, mycorrhiza, the dynamics of germination

\section{UVOD I CILJ ISTRAŽIVANJA}

Pri generativnom razmnožavanju ukrasnih biljnih vrsta često dolazi do problema sporog nicanja što poskupljuje troškove proizvodnje. Brzina nicanja sjemena kod trajnica različita je kao i kod biljnih vrsta drugih skupina. Kod pojedinih vrsta potrebno je svega pet do deset dana za nicanje, a nekima je potrebno i više od mjesec dana.

Za uspješan razvoj proizvodnje trajnica potrebno je ovladavanje njihovom tehnologijom uzgoja te troškove proizvodnje svesti na minimum s ciljem postizanja konkurentnosti na tržištu. U svrhu smanjenja troškova proizvodnje poželjan je što kraći period od sjetve do nicanja, što se može postići primjenom biljnih hormona, raznim kemijskim tretmanima i/ili inokulacijom supstrata za sjetvu mikoriznim gljivama. Za dobro razvijene, kvalitetne trajnice, vrlo su važni mikroelementi i makroelementi u supstratu, kao i sposobnost biljke da ih koristi. Mikoriza se često primjenjuje u uzgoju biljaka jer olakšava usvajanje hranjiva. Frank (1885.) je prvi uočio da korijenje mnogih vrsta šumskog drveća živi u zajednici s određenim vrstama gljiva. Tu pojavu nazvao je mikoriza. Naziv se zadržao do danas, no pojam je proširen na sve životne zajednice viših biljaka i gljiva, a ne samo na zajednicu drveća i gljiva (Potočić, 1983.). Važnost mikorize u ekološkom sustavu te kompleksnost mehanizma uspostavljanja interakcije gljive i biljke istraživali su brojni autori (Harley, 1971.; Raimam i sur., 2007.; Singh i sur., 2007.; Shenoy i sur., 2007.; Kiers i sur., 2011.; Smith i Smith, 2011.; Bahram i sur., 2013.; Phillips i sur., 2013.). 
Ines Han Dovedan i sur.: Utjecaj mikorize na nicanje koraljnog zvončića (Heuchera sanguinea 'Metallica')

Kod endomikorize hife micelija prodiru u stanice korijena i tako olakšavaju primanje hranjiva (Cayrol, 1991.). Gljive prodiru u korijen najviše do endoderme, ali nikad ne prodiru u vršni meristem (Pevalek-Kozlina, 2003.). Neki dijelovi hife su mnogo manjeg promjera od korijenovih dlačica $(2,3 \mu \mathrm{m}$ prema 10-20 $\mu \mathrm{m}$ ) što omogućuje prodiranje hifa i u najsitnije pore tla (Allen i Allen, 1984. prema Novak, 1998.). Biljka putem micelija postaje znatno sposobnija za upijanje mineralnih tvari i vode, postaje otpornija na bolesti i stres te brže raste (Matsubara i sur.; 2001., Kristek i sur., 2004.; Božac, 2005.; Kranjčev, 2005.; Miransari i sur., 2007.; Kernan i Marx, 2008.).

Brojna istraživanja na ukrasnim biljnim vrstama ukazuju na pozitivan utjecaj inokulacije sjemena s endomikoriznim gljivama roda Glomus koji se očituje u bržem nicanju sjemena, boljem razvoju listova, cvjetnih pupova i cvatova. Kranjčev (2005.) navodi da je kod orhideja za početni razvoj biljke neophodna prisutnost odgovarajuće vrste gljivica u tlu. Naime, sjemenka s micelijem određene vrste gljiva stupa u simbiozu, odnosno endomikorizu. Ako je endomikoriza u tlu uspješno postavljena, tj. ako je sjemenka svojim fungicidnim djelovanjem ograničila djelovanje gljivica samo na dio embrija, ili u suprotnom slučaju, ako gljivicu nije posve uništila, razvitak nove biljke bit će uspješan. Prema istraživanjima Aboul-Nasra (1995.) utjecaj Glomus etunicatum na Tagetes erecta L. i Zinnia elegans Jacq., pokazuje bujniju i raniju cvatnju i neovisnost o promjenama fosfora, kalija i natrija u biljkama. Židovec i sur. (2008.) istražili su utjecaj vezikularno-mikorizne gljive Glomus mossae na sjeme Tagetes patula posijano u inokulirani supstrat. Mikoriza je pozitivno utjecala na vrstu Tagetes patula u usporedbi s kontrolnom grupom, posebno na svojstva kao što su: broj razvijenih listova, cvjetnih pupova i cvatova. Družić Orlić i sur. (2005.) smatraju da se primjenom endomikoriznih gljiva i odabirom optimalnih simbioznih partnera može unaprijediti rasadničarska proizvodnja. Inokulacija mikropropagacijom dobivene podloge MrS 2/5 (Prunus cerasifera L.) s arbuskularno-mikoriznim gljivama roda Glomus pozitivno je utjecala na preživljavanje transplantacijskog stresa, rast i razvoj podloga te sadržaj fosfora u lišću. Podloge inokulirane s Glomus mossae, a zatim i s Glomus coronatum pokazale su se kao najuspješnija simbiozna kombinacija.

Svojstvo biljke da osim lijepog cvijeta posjeduje i zanimljive listove, vrlo je poželjno kod primjene ukrasnog bilja. Te karakteristike utječu i na primjećivanje cvjetnih gredica u gradskim prostorima (Poje i sur., 2013.). Iako je cvijet u većini slučajeva odlučujući prilikom odabira neke vrste, krajobrazni arhitekti ne smiju zaboraviti da cvatnja traje ograničeno vrijeme, dok je razdoblje u kojem biljka lista puno dulje, odnosno traje cijele godine kod 
Ines Han Dovedan i sur.: Utjecaj mikorize na nicanje koraljnog zvončića (Heuchera sanguinea 'Metallica')

zimzelenih vrsta. Odabirom biljnih vrsta koje osim zanimljiva cvijeta posjeduju i atraktivno lišće, produljuje se privlačan izgled zelene površine kroz cijelu godinu. Osim zimzelenih listova, osobito su zanimljive biljke s prošaranim listovima, vrste izrazito velikih ili malih, sjajnih odnosno dlakavih listova. Njihovom kombinacijom mogu se dobiti vrlo kreativna i zanimljiva krajobrazna rješenja. Jedne od trajnica takvih karakteristika su vrste roda Heuchera L. koji potječe iz Sjeverne Amerike, a neke vrste pronađene su u planinama Meksika. Danas rod Huchera L. broji oko 70-tak vrsta (Krüssmann i sur., 1970.). Samo u Sjevernoj Americi nalazi se oko 50 samoniklih vrsta (Hickman, 1993.). Koraljni se zvončić uzgaja radi dekorativnih zimzelenih listova privlačnih boja i gracilnih cvjetova različitih boja (Sterndale-Bennett, 2006.). Brojni hibridi razvijeni su križanjem vrsta Heuchera sanguinea Engelm. i Heuchera x brizoides Lemoine, a postoje i brojni kultivari koji se znatno razlikuju po boji lišća (Armitage, 1997.).

Cilj ovog rada je utvrditi utjecaj endomikorizne gljive Glomus mossae na dinamiku nicanja sjemena i razvoj listova kultivara Heuchera sanguinea Engelm. 'Metallica'.

\section{MATERIJALI I METODE}

Istraživanje je provedeno u gradu Zagrebu na Obiteljskom gospodarstvu Vidmar tijekom mjeseca srpnja, kolovoza i rujna 2010. godine.

Praćena je dinamika nicanja i razvoj listova kod kultivara Heuchera sanguinea Englem. 'Metallica'. Kultivar se odlikuje listovima boje mahagonija, bronce, aluminija ili srebra što im daje metalni sjaj, najizraženiji na mladim listovima u proljeće. Cvijet je u nijansama ružičaste i bijele boje, a cvate u proljeće - ljeto. Otporan je na mraz, voli sjenovita mjesta, a zahtjevi za vodom su mali.

Za potrebe istraživanja, za sjetvu je korišten višenamjenski industrijski supstrat EN standard Supstrat 1 proizvođača Klasmann koji se preporuča za sjetvu i proizvodnju spororastućih i na sol osjetljivih biljaka, te za uzgoj biljaka u malim posudama do $9 \mathrm{~cm}$. Supstrat, mješavina slabo razgrađenog bijelog treseta $(\mathrm{H} 2-\mathrm{H} 5)$ i crnog treseta $(\mathrm{H} 6-\mathrm{H} 8)$ imao je sljedeće karakteristike: električna provodljivost: $30 \mathrm{mS} / \mathrm{m}(+/-25 \%) ; \mathrm{pH}$ vrijednost $\left(\mathrm{H}_{2} \mathrm{O}\right): 5,5-6,5$; ukupna količina dodanog gnojiva (NPK 14:16:18): $1,0 \mathrm{~kg} / \mathrm{m}^{3}$; sadržaj teških metala nalazi se ispod maksimalno dozvoljenih koncentracija (MDK), propisanih Pravilnikom o zaštiti poljoprivrednog zemljišta od onečišćenja štetnim tvarima (NN br.15/92) mg/kg; Zn 62,43; Cu 19,54: Cd 0,621; $\mathrm{Pb} 21,22$; Mo 0,221; Ni 9,72; Cr 5,87; $\mathrm{Hg}<0,01$; As 0,0987; Co 6,11; Agronomski fakultet Sveučilišta u Zagrebu, Zavod za ishranu bilja, Broj 192-12/06. 
Ines Han Dovedan i sur.: Utjecaj mikorize na nicanje koraljnog zvončića (Heuchera sanguinea 'Metallica')

Inokulum sa sporama endomikorizne gljive Glomus mossae za ovo istraživanje proizveden je na Zavodu za povrćarstvo Agronomskog fakulteta Sveučilišta u Zagrebu.

Sjeme je nabavljeno od certificirane europske sjemenarske kuće Jelitto iz Njemačke. U jednom gramu ima prosječno 25000 sjemenki, klijavosti oko 60 \%.

Po 300 sjemenki posijano je u plastične posude volumena $1400 \mathrm{ml}$. Dimenzije posuda su iznosile $19,50 \mathrm{~cm}$ x $19,50 \mathrm{~cm}$ x $3,70 \mathrm{~cm}$, s poklopcima istih dimenzija.

\section{METODE ISTRAŽIVANJA}

U prethodno steriliziran supstrat kroz 45 minuta na $220^{\circ} \mathrm{C}$, nakon hlađenja provedena je inokulacija endomikoriznom gljivom Glomus mossae u koncentracijama od $0 \%$ vol. (K0),

$2,5 \%$ vol. (K1) i $5 \%$ vol. (K2). Sjetva je provedena početkom srpnja u posude volumena $1400 \mathrm{ml}$, tako da je za koncentraciju od 2,5\% vol. (K1) u supstrat dodano $35 \mathrm{ml}$ inokuluma, a za koncentraciju od 5\% vol. (K2) dodano je $70 \mathrm{ml}$ inokuluma, (K0) je kontrolna grupa te nije inokulirana sporama endomikorizne gljive Glomus mossae. Za precizno provođenje inokulacije supstrata određenim koncentracijama spora endomikorizne gljive Glomus mossae, kao i za punjenje supstrata u posude, korištene su sterilne menzure.

$\mathrm{U}$ posude napunjene prethodno mikoriziranim supstratom $\mathrm{u}$ koncentracijama 2,5\% vol. (K1), i 5\% vol. (K2) te u kontrolu K0, posijano je sjeme koraljnog zvončića koje je zbog vrlo male krupnoće prethodno pomiješano $\mathrm{s}$ kremenim pijeskom steriliziranim 45 minuta na $220{ }^{\circ} \mathrm{C}$. Preporučeno je temperaturu tijekom klijanja održavati na 15 do $20{ }^{\circ} \mathrm{C}$, iako se može sijati i kod drugih temperaturnih vrijednosti. U našem pokusu u vrijeme sjetve srednja temperatura zraka bila je $20,8{ }^{\circ} \mathrm{C}$. Sjeme je sijano u redove. Nakon sjetve posude su navlažene vodom finim rasprskivačem i stvarana pogodna mikroklima za inokulaciju i nicanje sjemena.

U pokusu su postavljene tri varijante inokululiranog supstrata sa sporama Glomus mossae, prva varijanta u koncentraciji od 2,5\% vol. inokuluma (K1), a druga u koncentraciji od 5\% vol. (K2) inokuluma, te kontrolna varijanta koja nije bila inokulirana.

Tijekom pokusa provedeno je ukupno devet mjerenja u svrhu utvrđivanja dinamike nicanja sjemena i razvoja listova. 
Ines Han Dovedan i sur.: Utjecaj mikorize na nicanje koraljnog zvončića (Heuchera sanguinea 'Metallica')

Podaci dobiveni praćenjem dinamike nicanja i razvoja listova, na kraju pokusa statistički su obrađeni metodama deskriptivne statistike, pomoću računalnog programa SPSS.

\section{REZULTATI ISTRAŽIVANJA}

Povećanje koncentracije inokuluma endomikorizne gljive Glomus mossae u supstratu utjecalo je na dinamiku nicanja, pojavu kotiledone i razvoj listova kod koraljnog zvončića, osim kod supstrata inokuliranog s 2,5\% vol. inokuluma (K1), gdje je kontrolna grupa s $0 \%$ vol. inokuluma (K0), pokazala bolje rezultate kod razvoja listova (grafikon 1).

\section{ukupan broj biljaka}

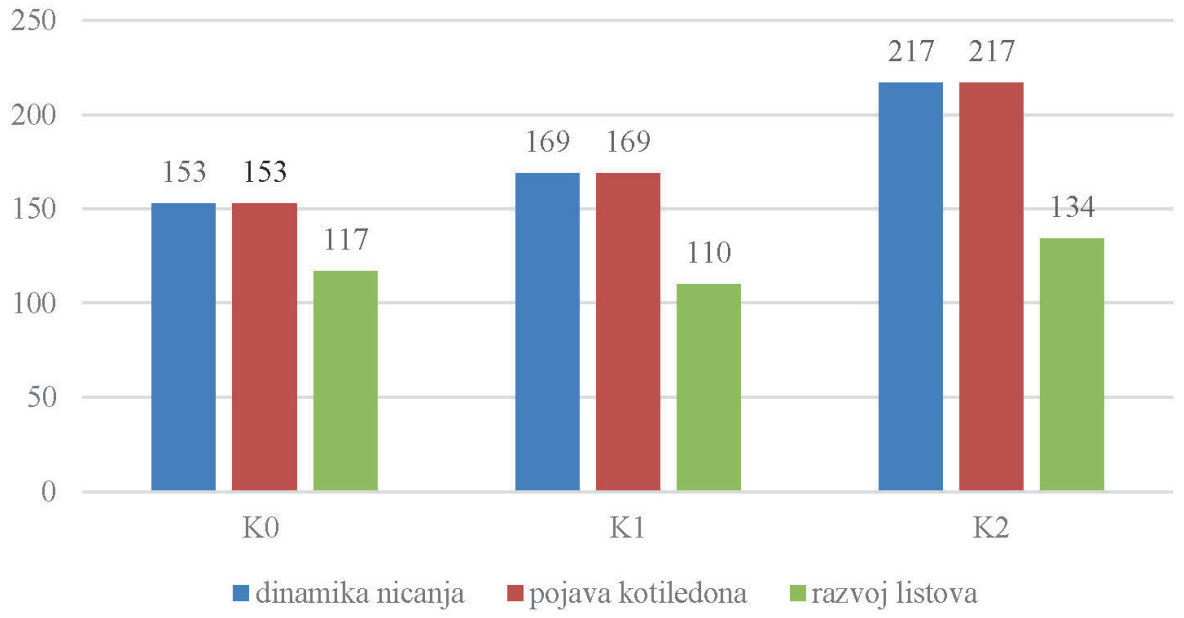

Grafikon 1. Ukupan broj biljaka dobiven na kraju pokusa za dinamiku nicanja, pojavu kotiledona i razvoj listova kod različitih koncentracija endomikorizne gljive Glomus mossae u supstratu, izražen brojčanim vrijednostima.

Chart 1 Total number of plants obtained after completion of the experiment for seed germination dynamics, formation of cotyledons and leaves development at various concentrations of endomycorrhizal fungus Glomus mossae in the substrate

\subsection{Dinamika nicanja}

Prema dobivenim podacima za dinamiku nicanja (grafikon 1) utvrđena je razlika između supstrata inokuliranog s 2,5\% vol. (K1) i 5\% vol. inokuluma (K2), u usporedbi s kontrolnom grupom $0 \%$ vol. inokuluma (K0). 
Ines Han Dovedan i sur.: Utjecaj mikorize na nicanje koraljnog zvončića (Heuchera sanguinea 'Metallica')

Supstrat K1 dao je bolje rezultate dinamike nicanja za 9,46\% u usporedbi s kontrolnom grupom.

Supstrat K2 dao je bolje rezultate dinamike nicanja za 29,5\% u usporedbi s kontrolnom grupom.

Između supstrata K1 i K2 utvrđena je razlika u dinamici nicanja od 20,29\% $\mathrm{u}$ korist supstrata s većom koncentracijom inokuluma (K2).

Iz grafikona 2. vidljiva je razlika u dinamici nicanja po terminima praćenja. Vrhunac dinamike nicanja postignut je 38 dana od sjetve (9. kolovoza) kod supstrata K2, a iznosio je 55 izniklih biljaka što je za 18,19\% više od supstrata $\mathrm{K} 1$, koji je vrhunac dinamike nicanja postigao 31 dan od sjetve (2. kolovoza), a iznosio je 45 izniklih biljaka.

Kontrolna grupa vrhunac dinamike nicanja postigla je 31 dan od sjetve (2. kolovoza), a iznosio je 41 izniklu biljku, što je za $25,45 \%$ manje od supstrata K2 i za 8,88\% manje od supstrata K1.

Sjeme koraljnog zvončića kod supstrata K2 i K1 niknulo je za 14 dana od sjetve, dok je kod kontrolne grupe za nicanje bilo potrebno 17 dana od sjetve do nicanja, kao što se vidi na grafikonu 2.

\section{dinamika nicanja}

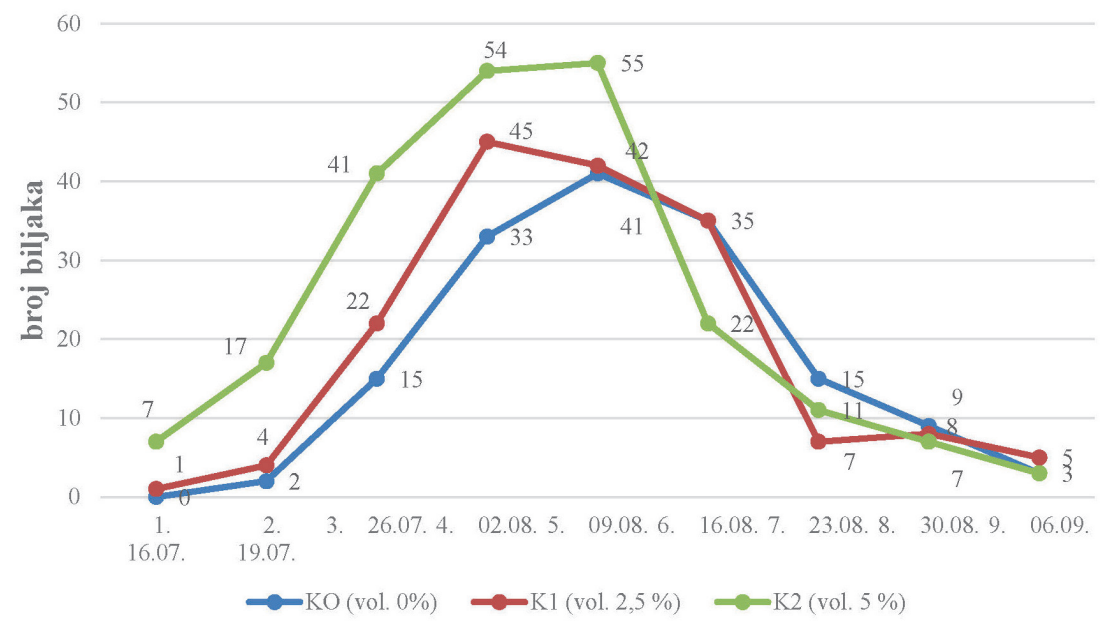

Grafikon 2. Dinamika nicanja, broj izniknulih biljaka po terminima praćenja izražen brojčanim vrijednostima

Chart 2. Germination dynamics depicted as number of sprouted plants per control terms 
Ines Han Dovedan i sur.: Utjecaj mikorize na nicanje koraljnog zvončića (Heuchera sanguinea 'Metallica')

\subsection{Razvoj listova}

Prema dobivenim podacima za razvoj listova vidljivih na grafikonu 1., utvrđena je razlika između supstrata K1 i K2, u usporedbi s kontrolnom varijantom $\mathrm{K} 0$.

Supstrat mikoriziran endomikoriznom gljivom Glomus mossae u koncentraciji od 2,5\% vol. (K1) dao je lošije rezultate kod razvoja listova za $5,98 \%$, u usporedbi s kontrolnom varijantom bez inokuliranja.

Supstrat K2 dao je bolje rezultate kod razvoja listova za 12,69\%, u usporedbi s kontrolnom grupom, a za 17,92\% u usporedbi s supstratom K1.

Iz grafikona 3. vidljiv je razvoj listova po terminima praćenja. Supstrat K2 pokazao je najbolje rezultate, 134 biljke s razvijenim listovima, što je za $17,91 \%$ više od supstrata K1 i za 12,68\% više od kontrolne grupe.

U supstratu K1 110 biljaka je razvilo listove, što je za 5,98\% manje od kontrolne grupe u kojoj je 117 biljaka razvilo listove.

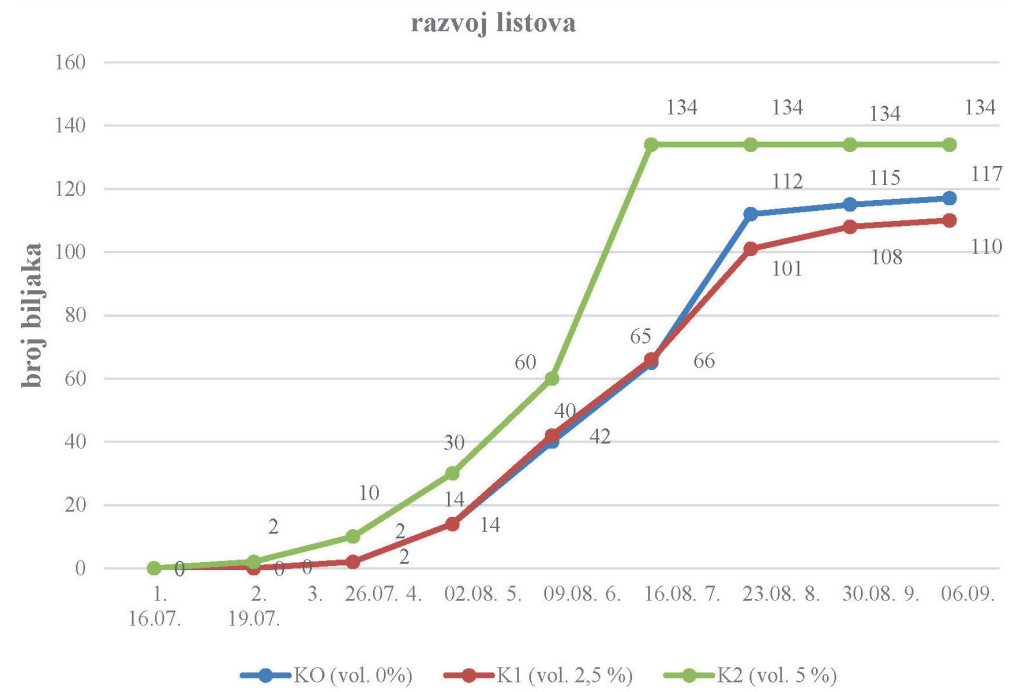

Grafikon 3. Broj biljaka s razvijenim listovima po terminima praćenja izražen brojčanim vrijednostima

Chart 3. Number of plants with developed leaves depicted as numbers per control terms 
Ines Han Dovedan i sur.: Utjecaj mikorize na nicanje koraljnog zvončića (Heuchera sanguinea 'Metallica')

\section{RASPRAVA}

Prema Nirmalasariju (2005.) spore Glomus mossae mogu klijati u alkalnom tlu ili na vodi ili tlu i ekstraktu agara kod pH 6-9. Reakcija supstrata korištenog u pokusu iznosila je 5,5 - 6,5, te nije mogla priječiti uspostavu mikorize, što se može vidjeti po dobivenim rezultatima.

Thangaswamy i Padmanabhan (2006.) potvrdili su utjecaj gljive Glomus fasciculatum na povećane razine hormona rasta. Barea i Azcon-Aguilar (1982.) prema Thangaswamy i Padmanabhan (2006.) ističu da mikorizne gljive proizvode auksin, giberelin i citokinin te potiču rast biljaka, što opravdava pozitivan rezultat učinka Glomus mossae na dinamiku nicanja u našem pokusu. Pozitivan učinak na rani rast sijanaca drvenastih vrsta Eucalyptus grandis i Quercus costaricensis utvrdili su i Holste i sur. (2016.) te Barry i sur. (2015.) u pokusu sa sijancima vrste Eucalyptus obliqua. Cevallos i sur. (2016.) na orhidejama iz roda Cymbidieae također su utvrdili bolji rast uz prisutnost mikoriznih gljivica. Povećanje koncentracije inokuluma endomikorizne gljive Glomus mossae u supstratu utjecalo je na dinamiku nicanja kod koraljnog zvončića. Supstrat inokuliran s 5\% vol. inokuluma (K2) dao je bolje rezultate u usporedbi s kontrolnom grupom $0 \%$ vol. inokuluma $(\mathrm{K} 0)$, kod dinamike nicanja za $29,5 \%$. Supstrat inokuliran s 2,5\% vol. inokuluma (K1), dao je bolje rezultate $\mathrm{u}$ usporedbi s kontrolnom grupom $0 \%$ vol. inokuluma (K0), kod dinamike nicanja za 9,46\%. Također je potvrđena razlika između supstrata inokuliranog s $2,5 \%$ vol. (K1) i 5\% vol. inokuluma (K2), u korist supstrata s većom koncentracijom inokuluma 5\% vol. (K2), kod dinamike nicanja za 20,29\%.

Rezultati utjecaja Glomus mossae na razvoj listova kod Heuchera sanguinea Englem. 'Metallica' pokazuju bolji razvoj listova kod veće koncentracije inokuluma u supstratu, 5\% vol. (K2), u usporedbi s kontrolom za $12,69 \%$, i za 17,92\% bolji razvoj listova u usporedbi s koncentracijom od 2,5\% vol. inokuluma (K1). Prema istraživanjima Aboul-Nasr (1995.) primjena Glomus etunicatum na Tagetes erecta L. i Zinnia elegans Jacq. rezultira bujnijom i ranijom cvatnjom. Židovec i sur. (2008.) istražili su utjecaj vezikularno-mikorizne gljive Glomus mossae na sjeme Tagetes patula zasijano $\mathrm{u}$ inokulirani supstrat. Inokulacija supstrata imala je pozitivne učinke na Tagetes patula u usporedbi s kontrolnom grupom, pogotovo u karakteristikama kao što su broj razvijenih listova, cvjetnih pupova i cvatova.

Javaid i Riaz (2008.) su ustanovili da su cvatnja i vegetativni rast gladiola bolji kod biljaka mikoriziranih u ranom stadiju rasta u odnosu na mikorizaciju u kasnijim fazama rasta, što može objasniti povećanu dinamiku nicanja kod supstrata inokuliranog s 2,5\% vol. (K1) i 5\% vol. inokuluma (K2) u prvih pet praćenja (38 dana od sjetve). 
Ines Han Dovedan i sur.: Utjecaj mikorize na nicanje koraljnog zvončića (Heuchera sanguinea 'Metallica')

Pad dinamike nicanja vidljiv je u četvrtom praćenju (31 dan nakon sjetve) kod supstrata K1. Istovremeno s padom dinamike nicanja zabilježen je pojačan razvoj mahovine u uzgojnoj posudi. Kod $\mathrm{K} 1$ izostao je pozitivan rezultat u usporedbi s K0, kod razvoja listova za 5,98\%. Razlog tome može biti pojava mahovine kod drugog praćenja (17 dana nakon sjetve), koja je do šestog praćenja (45 dana nakon sjetve) razvoja listova prekrila gotovo cijelu uzgojnu posudu, i time onemogućila daljnji rast i razvoj biljaka. Linderman i Davis (2004.) spominju da se ne može predvidjeti rast biljaka inokuliranih mikoriznim gljivama, već može pretpostaviti da će se rast mijenjati ovisno o genotipu inokulirane vrste i samog inokuluma, točnije njihova odnosa.

Utami (2001.) govori da će se kod slabog intenziteta svjetla smanjiti mikorizacija korijena, dok će se povećanjem intenziteta svjetla i duljine dana obično povećati i mikorizacija korijena. Tijekom pokusa mahovina je zauzimala sve veću površinu unutar zasijane posude s $2,5 \%$ vol. (K1) inokuluma, i stvorila za male biljke nepropustan sloj za svjetlost. Može se pretpostaviti da je pojava mahovine utjecala na smanjenu mikorizaciju korijena, a time i razvoj listova u supstratu inokuliranom s $2.5 \%$ vol. inkuluma (K1).

\section{ZAKLJUČNA RAZMATRANJA}

Povećanje koncentracije inokuluma endomikorizne gljive Glomus mossae u supstratu pozitivno je utjecalo na dinamiku nicanja kod koraljnog zvončića.

Nasuprot tome, povećanje koncentracije inokuluma nije utjecalo na intenzivniji razvoj listova kod koncentracije 2,5\% vol., ali je zabilježen bolji razvoj listova kod koncentracije 5\% vol.

Od sjetve do nicanja bilo je potrebno 14 dana kod inokuliranog supstrata, i 17 dana kod supstrata bez inokulacije.

Kod inokuliranog supstrata bilježi se brža dinamika nicanja, veći broj biljaka s razvijenim listovima zabilježen je kod koncentracije inokuluma od $5 \%$ vol. u usporedbi s kontrolnom grupom.

Uporabom endomikorizne gljive Glomus mossae može se smanjiti vrijeme od sjetve do nicanja, kod koraljnog zvončića, međutim razlika je neznatna, i time se neće znatno smanjiti troškovi proizvodnje. Svakako se preporuča uporaba Glomus mossae u svrhu postizanja brže dinamike nicanja kao i nastavak istraživanja utjecaja Glomus mossae na ostala svojstva. 
Ines Han Dovedan i sur.: Utjecaj mikorize na nicanje koraljnog zvončića (Heuchera sanguinea 'Metallica')

\section{LITERATURA}

1. Aboul-Nasr A. (1995.): Effect of vescular-arbuscular mycorrhiza on Tagetes erecta and Zinia elegans. Mycorrhiza 6(1): 61-64

2. Armitage A. (1997.): Herbaceous perennial plants a treatise on their identification, culture and garden attributes stipes publishing, L.L.C. Illinois pp. 526.

3. Bahram M., Koljalg U., Kohout P., Mirshahvaladi S., Tedersoo L. (2013.): Ectomycorrhizal fungi of exotic pine plantations in relation to native host trees in Iran: evidence of host range expansion by local symbionts to distantly related host taxa. Mychorhiza 23:11-19.

4. Barry K.M., Janos D.P., Nicholos S., Bowmann D.M. (2015.): Eucalyptus obliqua seedlings growth in organic vs. mineral soil horizons. Front Plant Sci 6:97. Doi: 10.3389/fpls.2015.00097

5. Božac R. (2005.): Enciklopedija gljiva 1. Školska knjiga, Zagreb, 33-35.

6. Caron M., Fortin J.A., Richard C. (1986.). Effect of phosphorus concentration and Glomus intraradicens on Fusarium crown and rot of tomatoes. Phytopathology, 76: 942-946.

7. Cayrol J.C. (1991.): Proprietes nematicides des endomycorhizes a vesicules et arbuscules P.H.M. Revue Horticulture 321:33-42.

8. Cevallos S., Sanches-Rodriguez A., Decock C., Declerck S., Suarez J.P. (2016.): Are there keysone mycorrhizal fungi associated to tropical epiphytic orchids? Mycorrhiza. doi: 10.1007/s00572-016-0746-8

9. Družić Orlić J., Čmelik Z., Redžepović S. (2005.): Utjecaj arbuskularnomikoriznih gljiva roda Glomus na rast i razvoj podloge MrS 2/5 (Prunus cerascifera L.). Pomologia Croatica 11(3-4): 167-183.

10. Frank A.B. (1885.): Neue Mittheilungen über die Mycorhiza der Bäume und der Monotropa hypopitys. Ber Dtsch Bot Ges 3:XXVII-XXXIII.

11. Harley J.L. (1971.): Fugi in ecosystems. Journal of Applied Ecology 8: 627-642.

12. Hickman J.C. (1993.): The Jepson manual, higher plants of California. University of California Press. Berkeley, California. P. 1003

13. Holste E.K., Kobe R.K., Gehring C.A. (2016.): Plant species differ in early seedling growth and tissue nutrient responses to arbuscular and ectomycorrhizal fungi. Mycorrhiza. doi: 10.1007/s00572-016-0744-x

14. Javaid A., Riaz T. (2008.): Mycorrhizal colonization in different varietes of gladiolus and its realation with plant vegetative and reproductive growth. International Journal of Agriculture and Biology 10: 278-282. 
Ines Han Dovedan i sur.: Utjecaj mikorize na nicanje koraljnog zvončića (Heuchera sanguinea 'Metallica')

15. Kernan M., Marx D.H. (2008.): Mycorrhizal Fungi Can Reduce the Effects of Drought on Plants. Technical Bulletin 094 Plant Health Care Inc. 1-5

16. Kiers E.T., Duhamel M., Beesetty Y., Mensah J.A., Franken O., Verbruggen E., Fellbaum C.R., Kowalchuk G.A., Hart M.M., Bago A., Palmer T.M., West S.A., Vandenkoornhuyse P., Jansa J., Bücking H. (2011.): Reciprocal Rewards Stabilize Cooperation in the Mycorrhizal Symbiosis. Science 333: 880-882.

17. Kranjčev R. (2005.): Hrvatske orhideje. Agencija za komercijalnu djelatnost, Zagreb.

18. Kristek S., Kristek A., Pavlović H. (2004.): Effect of G. mossae and G. intraradices on field pea plants survival and growth in the drought caused stress conditions. Energy efficiency and agricultural engineering. Rousse, Bulgaria. Abstract 247-249

19. Krüssmann G., Siebler W., Tangermann W. (1970.): Winterharte Gartenstauden. Veralg Paul Parey Berlin und Hamburg, 89-90.

20. Liderman G.R., Davis E.A. (2004.): Varied response of marigold (Tagetes spp.) genotipes to inoculation with different arbuscular mycorrhizal fungi. Scientia Horticulture, 99: 67-78.

21. Matsubara Y., Ohba N., Fukui H. (2001.): Effect of arbuscular mycorrhizal fungal infection on the incidence of fusarium root rot in asparagus seedlings. Japan.Soc.Hort.Sci 70(2): 202-206.

22. Miransari M., Bahrami H. A., Rejali F., Malakouti M. J. Torabi H. (2007.): Using arbuscular mycorrhiza to reduce the stressful effects of soil compaction on corn (Zea mays L.) growth. Soil Biology and Biochemistry 39(8): 2014-2026

23. Nirmalasari (2005.): Keberadaan Cendawan Mikoriza Arbuskula (CMA) Pada Tegakan Durian (Durio zibethinus Murr). Skripsi Fakultas Kehutanan UNTAN. Pontianak

24. Novak B. (1998.). Učinkovitost endomikorize na neke povrtne kulture. Poljoprivredna znanstvena smotra 63(4): 187-198.

25. Pevalek-Kozlina B. (2003.): Fiziologija bilja. Profil, Zagreb, 113-116.

26. Phillips R.P., Midgley M.G., Brozstek E. (2013.): The mycorrhizal-associated nutrient economy: a new framework for predicting carbon-nutrient couplings in temperate forests. New Phytol 199: 41-51.

27. Poje M., Vukelić A., Han Dovedan I. (2013.): Perception of Flower Beds in Public Green Areas. Agriculturae Conspectus Scientificus 78(2): 125-129.

28. Potočić Z. (1983.): Šumarska enciklopedija 2. Jugoslavenski leksikografski zavod, Zagreb 413-415. 
Ines Han Dovedan i sur.: Utjecaj mikorize na nicanje koraljnog zvončića (Heuchera sanguinea 'Metallica')

29. Raimam M.P., Albino U., Cruz M.F., Lovato G.M., Spago F., Ferracin T.P., Lima D.S., Goulart T., Bernardi C.M., Miyauchi M., Nogueira M.A., Andrade G. (2007.): Interaction among free-living N-fixing bacteria isolated from Drosera villosa var. villosa and AM fungi (Glomus clarum) in rice (Oryza sativa). Applied Soil Ecology 35(1): 24-34.

30. Shenoy B.D., Jeewon R., Hyde K.D. (2007.): Impact of DNA sequence-data on the taxonomy of anamorphic fungi. Fungal Diversity 26: 1-54

31. Singh R., Behl R. K., Jain P., Singh K.P., Narula N. (2007.): Performance and gene effects for root characters and micronutrient uptake in wheat inoculated with arbuscular mycorrhizal fungi and Azotobacter chroococcum. Acta Agronomica Hungarica 55(3): 325-330

32. Smith, S.E. Smith, F.A. (2011.). Roles of arbuscular mycorrhizas in plant nutrition and growth: new paradigms from cellular to ecosystems scales. Annu Rev Plant Biol. 62: 227-250.

33. Sterndale-Bennett J. (2006.). The Winter Garden. David \& Cherles by OutHouse Publishing, Winchester, 58-59

34. Thangaswamy S., Padmanabhan C. (2006.): Arbuscular mycorrhizae: A diverse personality. Journal Central European Agriculture 7(2): 349-358.

35. Utami, Retno. (2001.). Studi Keanekaragaman CMA Pada Beberapa Jenis Non Dipterocarpaceae Di Hutan Dataran Rendah Taman Nasional Gunung Palung Kabupaten Ketapang. Skripsi Fakultas Kehutanan UNTAN: Pontianak (Tidak diterbitkan)

36. Židovec V., Vršek I., Novak B., Bujan M., Ognjenovic T. (2008.): Effect of mycorrization on germination and growth of marigold. Cereal research communications 36(3): 1539-1542.

Adrese autora - Author's addresses:

Ines Han Dovedan, e-mail:ihan@agr.hr, Ana Brajković, Miroslav Poje

Sveučilište u Zagrebu, Agronomski fakultet, Svetošimunska cesta 25, 10000 Zagreb, Croatia
Primljeno - received: 28.08.2017. 
Ines Han Dovedan i sur.: Utjecaj mikorize na nicanje koraljnog zvončića (Heuchera sanguinea 'Metallica') 